\title{
動摇歯を含むブリッジの光弾性的研究
}

\author{
村上繁 樹*・田 中 眞理子** - 小 園 凱 夫*** \\ 内田康也* \\ *九州歯科大学歯科補経学第 2 講座（主任：内田康也教授） \\ ** 九州歯科大学物理学教室 (主任: 河野通郎教授) \\ *** 九州歯科大学歯科理工学講座 (主任：小園凱夫教授)
}

平成 8 年 2 月 26 日受理

\section{Photoelastic Analysis of Stress Distribution with Bridge Involving Mobile Abutment Tooth}
Shigeki Murakami*, Mariko Tanaka**, Yoshio Kozono*** and Yasunari Uchida*

\footnotetext{
${ }^{*}$ Second Department of Prosthetic Dentistry (Chief : Prof. Yasunari Uchida)

${ }^{* *}$ Department of Physics (Chief: Prof. Michio Kouno)

*** Department of Materials Science (Chief : Prof. Yoshio Kozono)

Kyushu Dental College, Kitakyushu, Japan
}

The present study photoelastically analysed stress distribution in the alveolar bone around the abutment teeth for a bridge involving mobile teeth. The mobile teeth in this study were limited to those which were lack of support because of their increased crown-root ratio. Four types of (4)(5) 6 (7) bridge models for a case $\sqrt{6}$ being absent and $\sqrt{5}$ mobile were used: type A, with normal $\sqrt{4}$ and mobile $\sqrt{7}$; type $\mathrm{B}$, with normal $\sqrt{4}$ and normal $\sqrt{7}$; type $\mathrm{C}$, with mobile $\sqrt{4}$ and mobile $\sqrt{7}$; and type $\mathrm{D}$, with mobile $\sqrt{4}$ and normal $\longdiv { 7 }$.

The mobility of a single mobile tooth was characterized by a typical Moiré fringe at its cervical portion in addition to its root apex under an eccentric vertical load. When $\longdiv { 5 }$ was connected with other abutments by a rigid bridge, the mobility of $\sqrt{5}$ was markedly decreased even if $\sqrt{4}$ and/or $\sqrt{7}$ were mobile. The analyses of stress distribution showed that the applied load through the bridge was primarily supported by the alveolar bone around $\sqrt{7}$ in any type. It was suggested from the foregoing results that the immobility of $\longdiv { 7 }$ might be essential for minimizing the mobility of the abutment teeth.

Key words: Mobile abutment tooth/Bridge/Stress distribution/Photoelastic analysis

\section{緒言}

少数菡久損補綴におけるブリッジの支台菊は，柬周組 織が健全で動摇がないことが原則である。しかし，臨床
の場では動摇歯を支台歯として選択しなくてはならない 症例に度々遭遇する．残存している動摇歯を支台歯とし て連結する場合には支台蒾の保全が問題となるり。動摇 歯を支台としたブリッジの成否は，歯周疾患の問題と咬 
合の問題をいかにブリッジの設計に取り入れるかにか かっているといえるる,3. その際，動摇歯を支台歯として 使用した場合に，咬合力を加えると歯槽骨内の他力分布 がどのように変化するのかを知る必要がある.

従来のブリッジに関する光弾吽的研究は, 歯周組織が 健全であると仮定して実験計画が市てられておりり ${ }^{48}$, 動 摇歯を想定した研究は少ない, ${ }^{900}$. そこで， 6 が久損し 「落動摇しているという条件で， 47 の支台歯歯槽骨

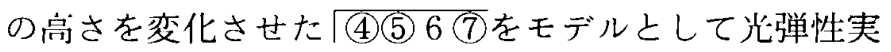
験を行ったので報告する.

\section{材料ならびに方法}

\section{I ，光弾性試験用モデルの作製}

本実験では歯冠一歯根長比が大きくなることによって 生じる動摇㐘を対象とし，予備実験において光弾性モア レパターンからピンを用いた健全歯および動摇歯モデル の歯冠一歯根長比を規定した。戍 1 は, 健全単根㐘を想 定して菊冠一㐘根長比を $1: 2$ とした場合のモアレパター ンを示す．ピン上部中心に長軸に沿って重直荷重（中央

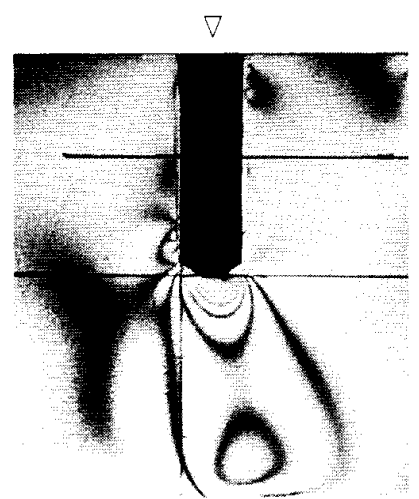

中央荷重

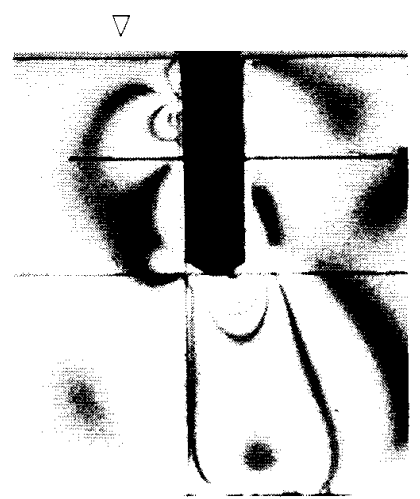

偏心荷重
図 1 健全歯に重真荷重 ( $\nabla$ 点)を加えた場合のモアレパターン $\nabla$

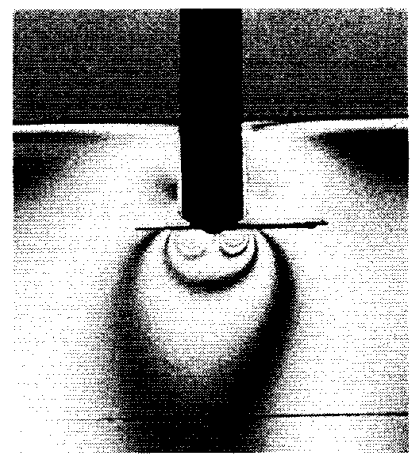

中央荷重 $\nabla$

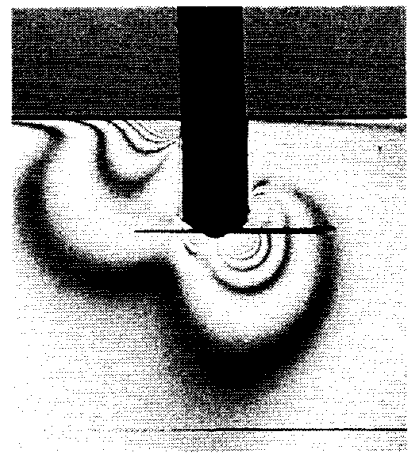

偏心荷重
図2 動摇歯に垂直荷重 ( $\nabla$ 点) を加えた埸合のモアレパターン
荷重）を加える之，根尖相当部周辺に応力集中がみられ た. ピン上部辺緣に垂淔荷重（偏心荷重）を加えた場 合，歯根相当部片側にもモアレが生じたが，ピンの傾向 を示す明確な傾向は認められなかった，歯冠一歯根長比 が大きくなり 2:1になると(図 2), 偏心荷重によって 肉眼的にもピンの傾斜が認められ，傾斜を示す典型的な モアレパターンとして歯頸部相当部の負荷側および反対 側根尖相当部に著しい応力集中が生じることがわかっ た. 吉江 (1991)" は㐘根の半分まで骨吸収している歯 であっても，炎症，ポケットが存在しなければ，健全歯 と同様, 支台雬として使用できると述べている。これら のことから，歯冠-歯根長比を $2: 1$ とした場合を動摇歯 のモデルとした。

光弾性試験用ブリッジモデルは, $\sqrt{6}$ が欠損, $\sqrt{5}$ が動 摇歯の場合の症例を想定し, (4)(5) 6(7)のブリッジを設 計した. 47 は健全歯あるいは動摇歯とし, 次の 4 通り の組み合わせで実験を行った。

タイプA: $\sqrt{4}$ が健全蒾で, 7 が動摇蒾

タイプB: $\sqrt{4}$ が健全蒾で,

タイプC: $\sqrt{4}$ が動摇㐘で, 7 が動摇㐘

タイプD: $\sqrt{4}$ が動摇歯で, 7 が健全㐘

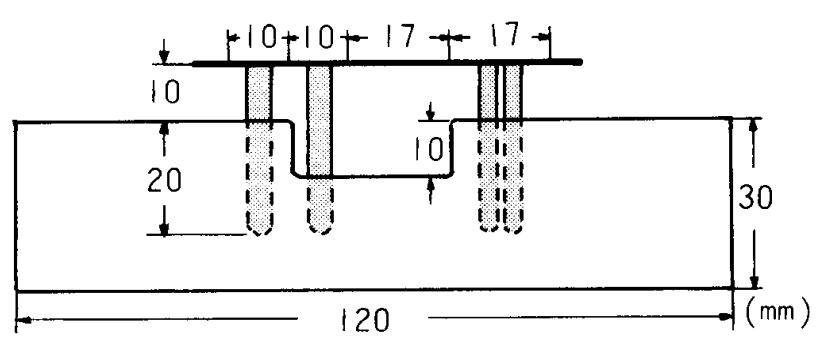

図 3 ブリッジ模型（タイプ B）の模式図

図 3 にブリッジモデルの例（タイプB）を示す，小臼 歯には直径 $4 \mathrm{~mm}$, 長さ $30 \mathrm{~mm}$ の真鍮ピンを 1 本, 大臼歯 には直径 $3 \mathrm{~mm}$, 長さ $30 \mathrm{~mm}$ の真鍮ピンを 2 本用いた。咬 合面部は厚さ $2 \mathrm{~mm}$, 幅 $6 \mathrm{~mm}$ 真鍮板を用い，それぞれの ピンの上端部を超速硬性常温重合レジンでしっかりと固 定した。

\section{II. 実験方法}

モデルを安定な水平台に設置し， $20 \mathrm{~kg}$ の垂直集中荷 重を加えた。単根歯の場合では歯根の軸上， 2 根歯では 2 根の中間軸上およびポンティックの中央部に荷重を加 えたすのを本実験における中央荷重とし，歯牙の隣接部 に荷重を加えた場合を偏心荷重とした。また，側方分力 を作用させるため，ピンの同部位で長軸に対して $10^{\circ}$ 傾 
斜した荷重（以下傾斜荷重という）が加わるように，モ デルを $10^{\circ}$ 傾斜させた場合についても実験を行った。 忍 力分布測定には，光弾性実験装置（PA-150 型，理研計 器）を使用した，光源には白色光源と水銀灯単色光源の 2 種類を用いた，ブリッジ.上の 9 力所に荷重を加え，そ れぞれの場合の 2 次元伈力状態での歯槽骨内の縞次数を 测定した.

\section{結果}

\section{I . 垂直中央荷重時の㕱力分布}

図 4 は支台菌に重直中央荷重が加わった場合の応力分 布の例を示している. 畄 4 灰はタイプAの動摇支台歯 「5に，図 4 右は夕イプ $\mathrm{B}$ の健全支台歯 $\sqrt{4}$ に中央荷重 が加わった場合で，いずれにおいても負荷された支台歯 の根尖部のみに垂直的な大きな就集中が生じ，他の部 位には応力の発生を示すモアレはみられなかった。タイ プあるいは支台柬が異なっても，健全蔽，動摇菊にかか
わらず，同様の傾向を示した.

タイプ A， B のポンティック中央部に中央荷重を加え た場合の応力分布を四 5 に示す。いずれにおいても,

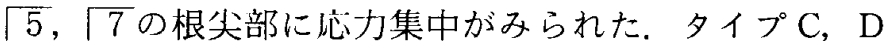
についても大きな違いは認められなかった。

II. 重直偏心荷重時の心力分布

各支台㐘の近心あるいは遠心隣接部に偏心荷重を加え た場合，いずれのタイプにおいて角荷がかかった支台 㐘の根尖部に大きな応力集中がみられた。タイプあるい は支台歯によっては，他の部位にも応力の発生が認めら れた。それらを表 1 にまとめ, 主なモアレパターンを図 $6 \sim 8$ に示す.

「40近心偏心荷重では（表 1 ，瓯 6 ），いずれのタイ プにおいても タイプ A では 4 の近心歯頸部および 7 の近心歯頸部 にわずかな応力集中が認められる。タイプ Cでも

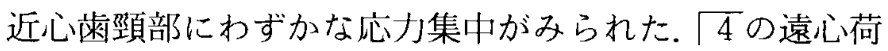
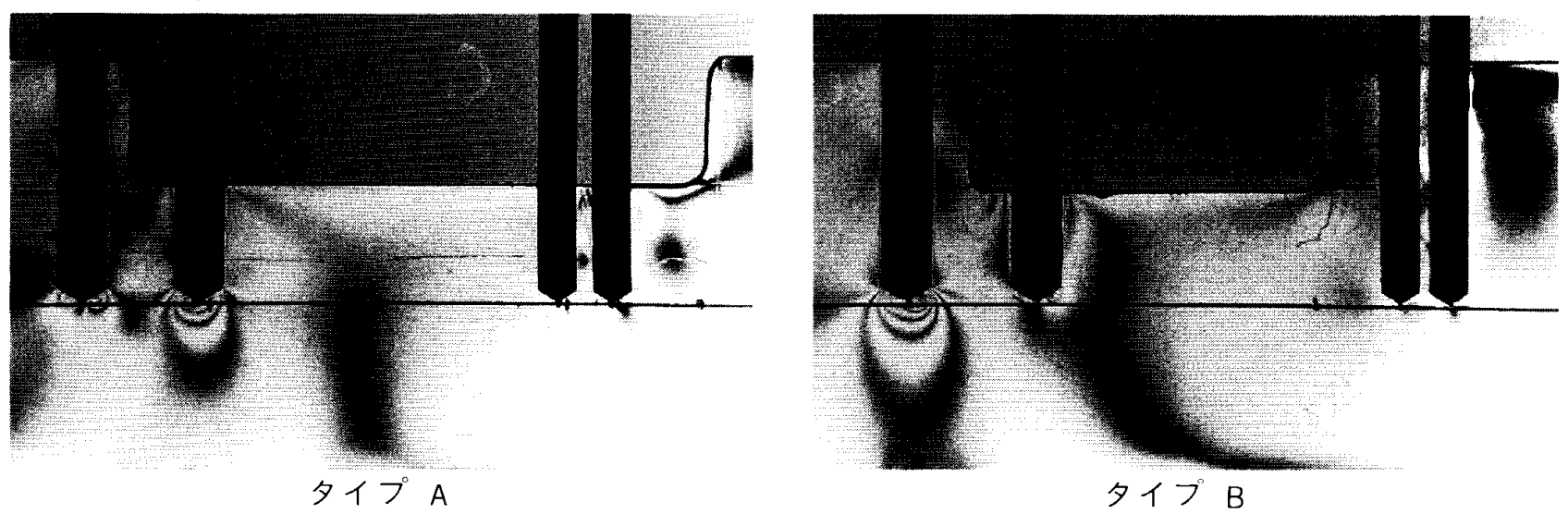

図 4 支台歯に垂直中大荷重（（点）を加えた場合のモアレパターン例
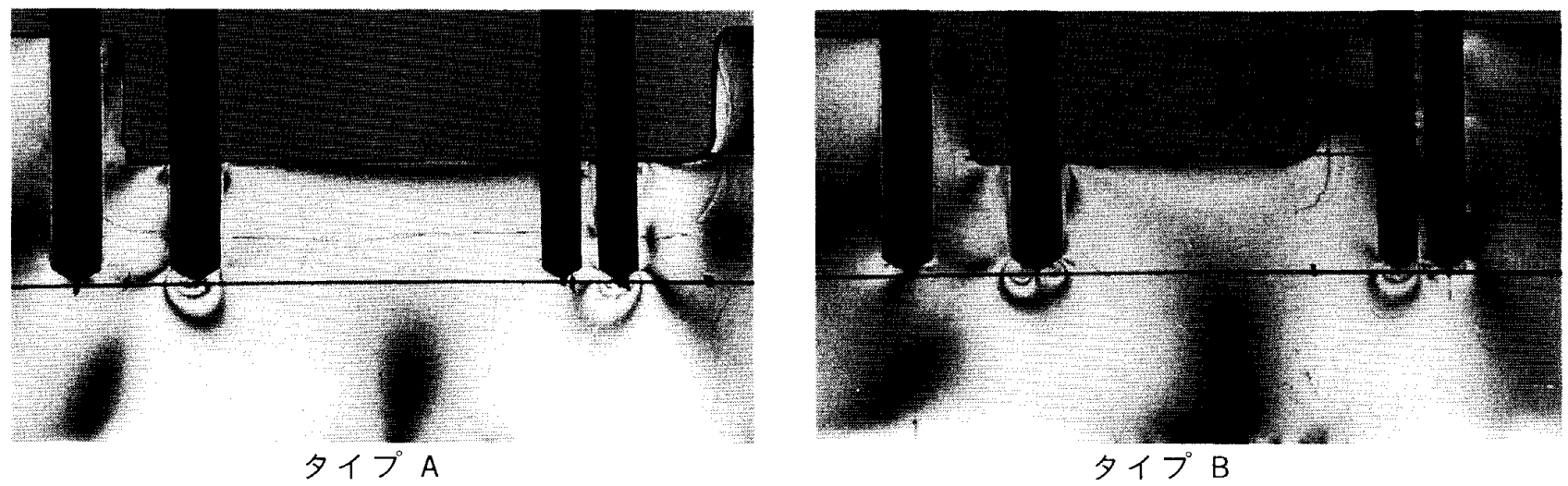

図 5 ポンティックに垂当中央荷重（、点）を玑えた埸合のモアレパターン例 
表 1 垂直偏心荷重下に㧍ける応力分布

\begin{tabular}{|c|c|c|c|c|c|c|}
\hline \multirow[b]{2}{*}{ 荷 重 点 } & \multirow[b]{2}{*}{ 部位 } & \multicolumn{4}{|c|}{ タイプ } & \multirow{7}{*}{$\begin{array}{l}\text { (4) (7) : : 健全㐘 } \\
\text { (4) } \\
++ \text { : 動摇茵 } \\
++ \text { : 縞次数 } 5 \text { 以 } 1 \\
++ \text { : 縞次数 } 3 、 4 \\
+ \text { : 縞次数 } 1 、 2\end{array}$} \\
\hline & & $\begin{array}{c}A \\
\text { (4) } 7\end{array}$ & $\begin{array}{c}\mathrm{B} \\
\text { (4) (7) }\end{array}$ & $\stackrel{C}{4}$ & $\begin{array}{c}D \\
\text { (4) (7) }\end{array}$ & \\
\hline$\sqrt{4}$ の近心 & 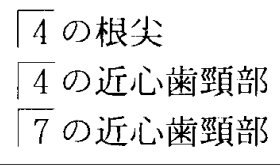 & $\begin{array}{r}++ \\
+ \\
+\end{array}$ & +++ & $\begin{array}{r}++ \\
+ \\
+\end{array}$ & +++ & \\
\hline$\sqrt{4}$ の遠心 & $\begin{array}{l}\Gamma 4 \text { の根尖 } \\
\qquad 5 \text { の根尖 }\end{array}$ & $\begin{array}{l}+++ \\
+++\end{array}$ & $\begin{array}{l}+++ \\
+++\end{array}$ & $\begin{array}{l}+++ \\
+++\end{array}$ & $\begin{array}{l}+++ \\
+++\end{array}$ & \\
\hline$\sqrt{5}$ の遠心 & $\begin{array}{l}\sqrt{5} \text { の根尖 } \\
\sqrt{7} \text { の遠心歯頸部 }\end{array}$ & $\begin{array}{r}++ \\
+\end{array}$ & +++ & +++ & +++ & \\
\hline 77 の近心 & $\begin{array}{l}77 \text { の根尖 } \\
7 \text { の遠心歯頸部 }\end{array}$ & $\begin{array}{r}++ \\
+\end{array}$ & +++ & $\begin{array}{c}++ \\
+\end{array}$ & +++ & \\
\hline $\mid 7$ の遠心 & 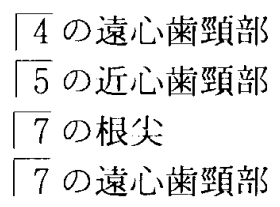 & $\begin{array}{r}+ \\
+ \\
+++\end{array}$ & $\begin{array}{r}++ \\
+\end{array}$ & $\begin{array}{c}+++ \\
+\end{array}$ & $\begin{array}{l}+++ \\
++\end{array}$ & \\
\hline
\end{tabular}
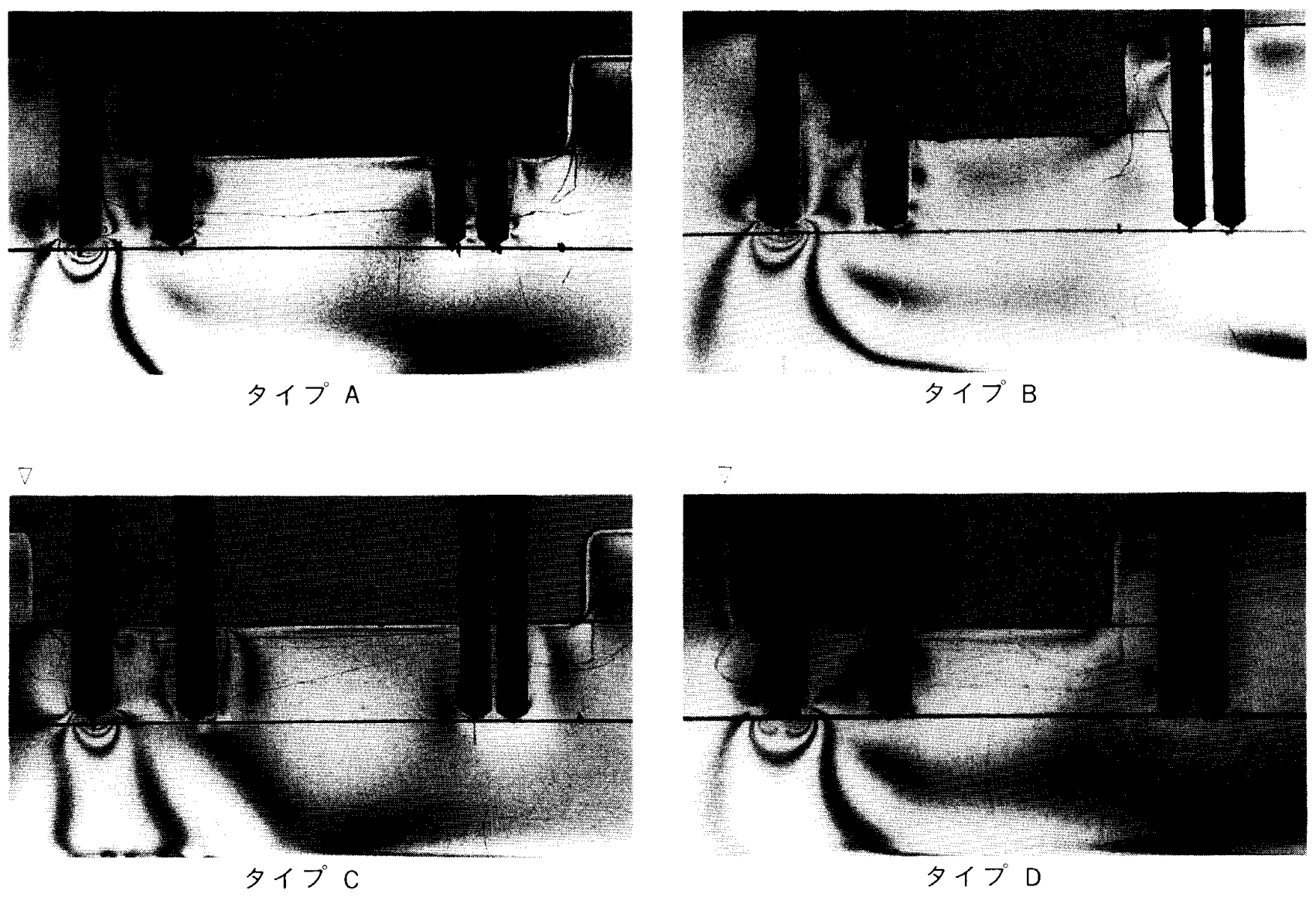

図6 $\sqrt{4}$ に垂直近心偏心荷重 $(\nabla$ 点)を加えた場合のモアレパターン 


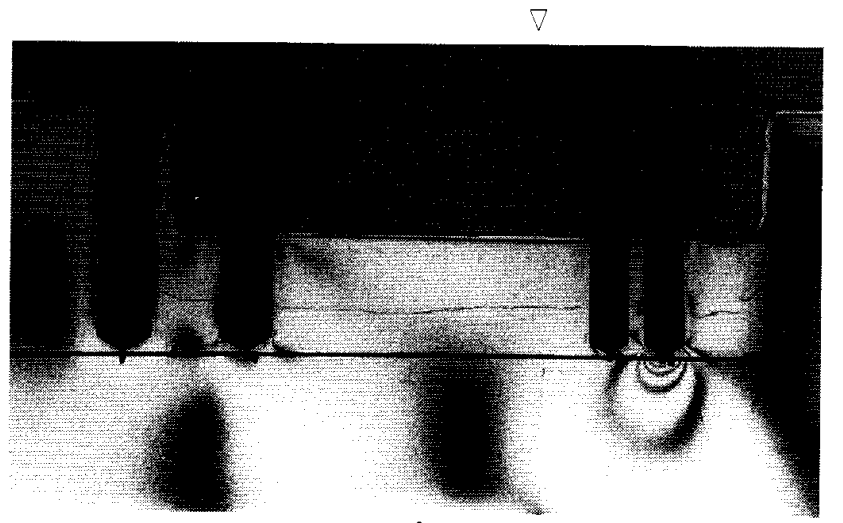

タイプA

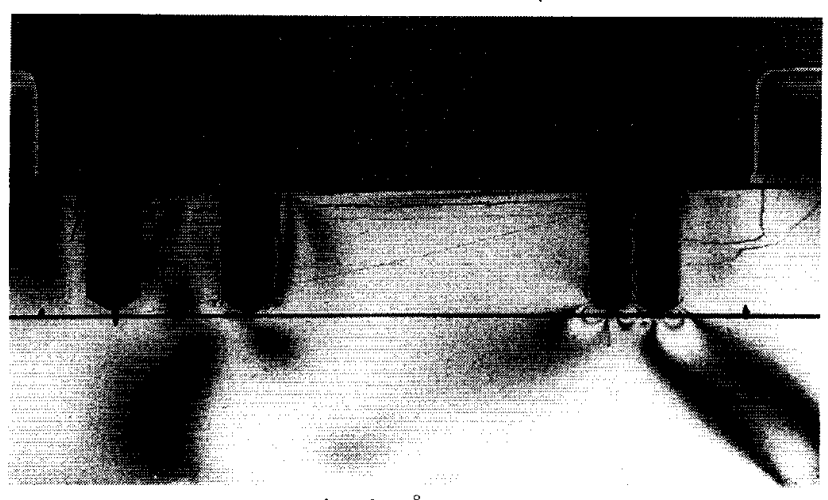

タイプ C
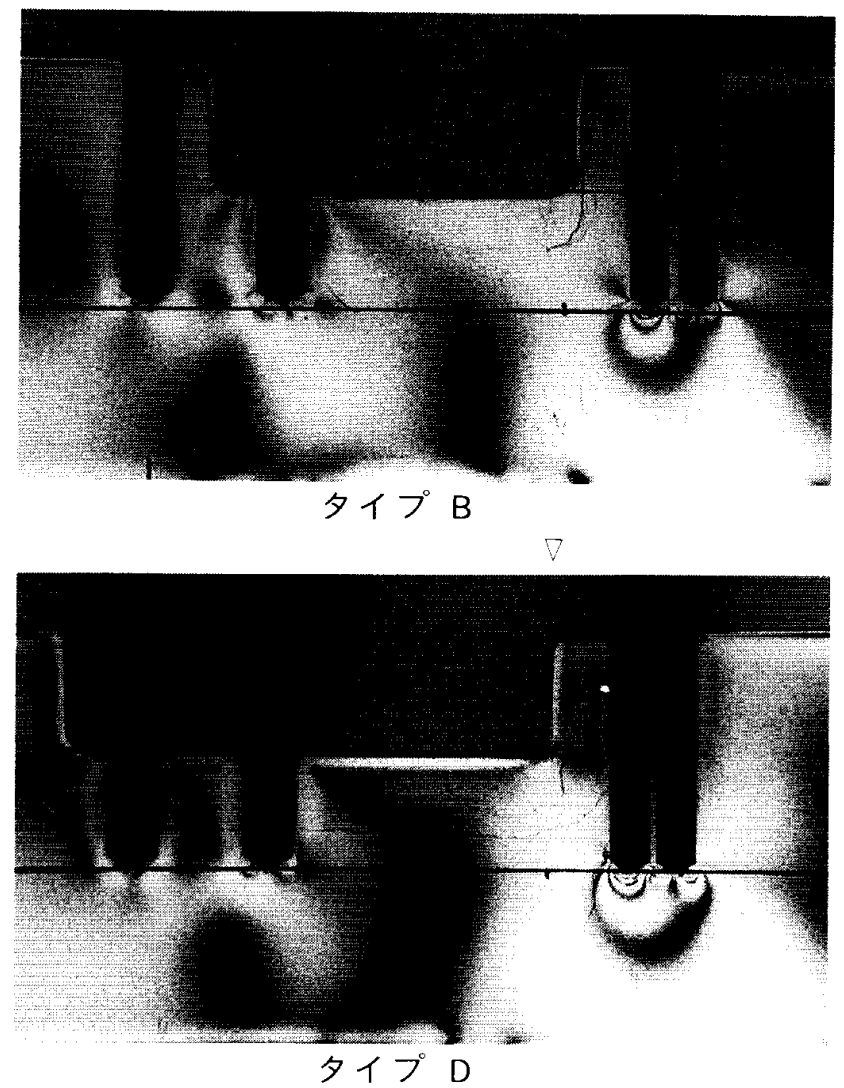

図 $7 \longdiv { 7 }$ に垂直近心偏心荷重（、点）を加えた場合のモアレパターン

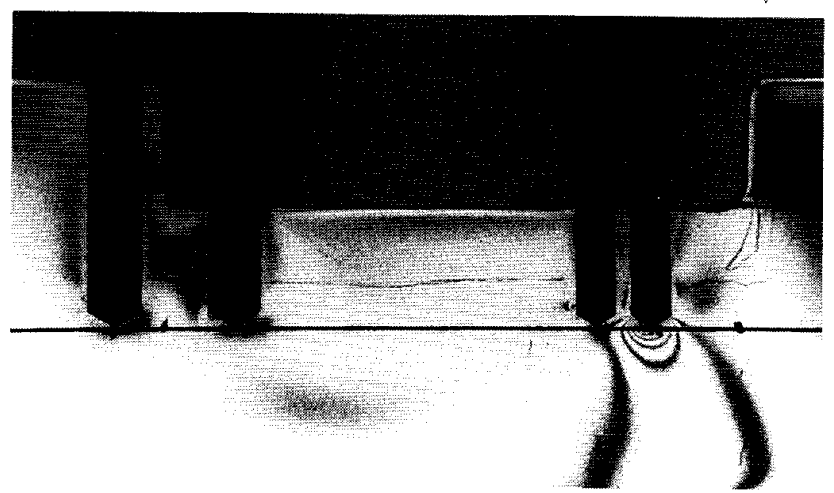

タイプA

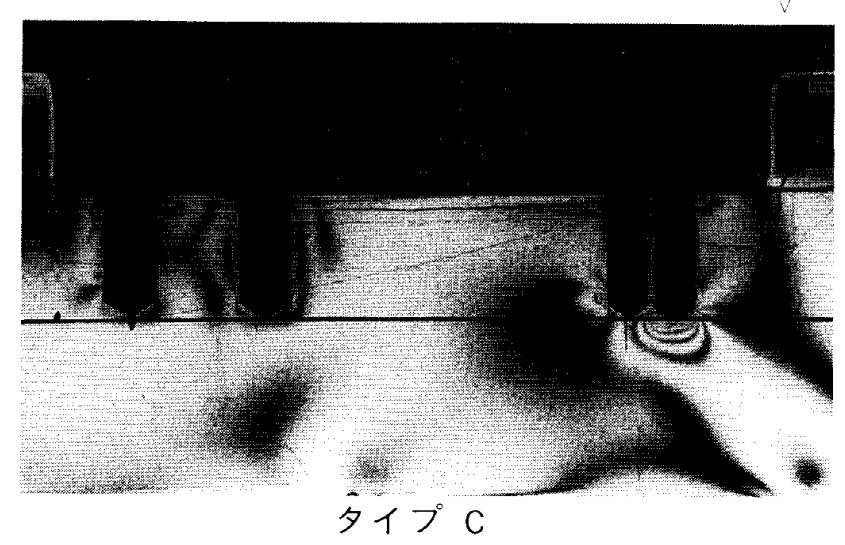

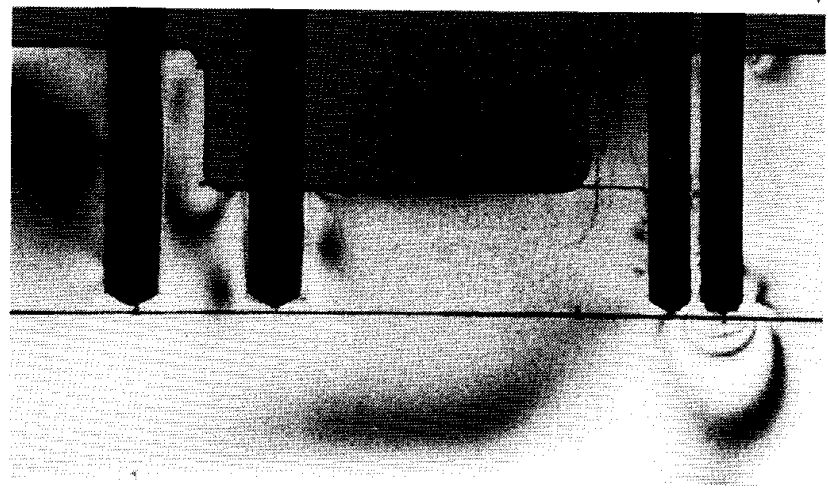

タイプ B

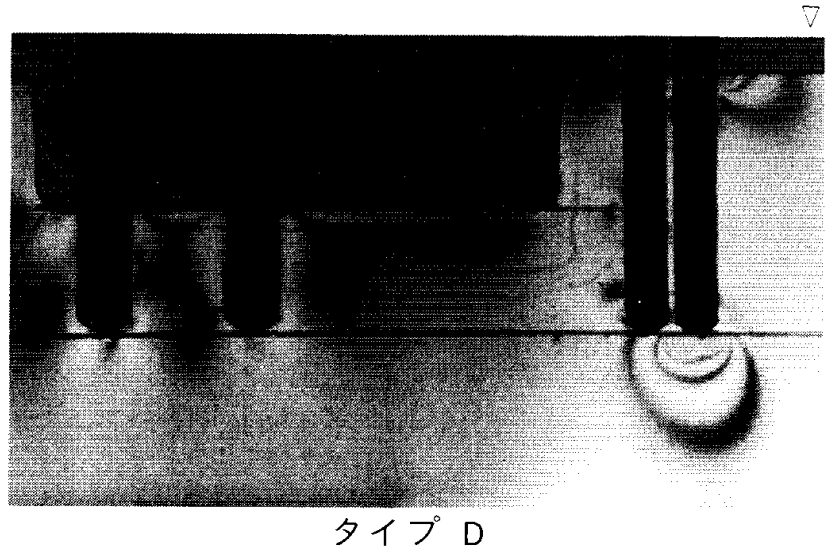

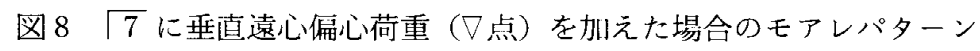




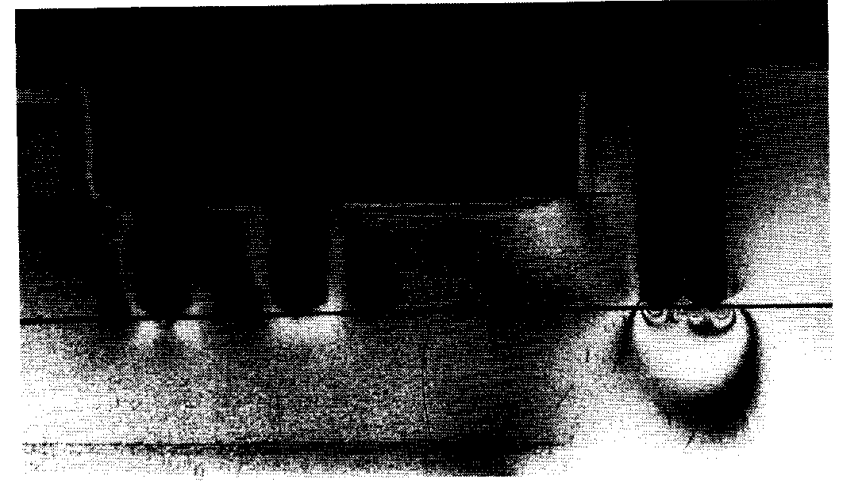

垂直荷重

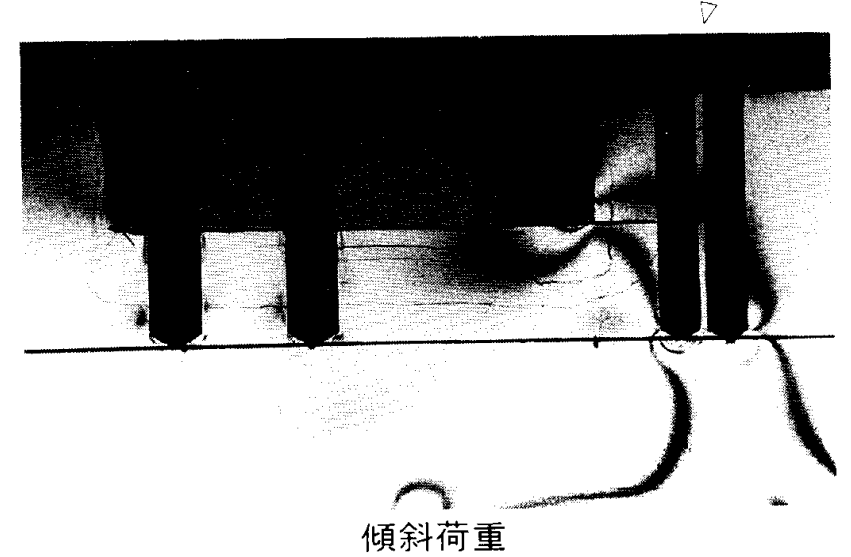

タイプD

図 9 垂直荷重（ $\nabla$ 点）と傾斜荷重（ $\nabla$ 点）との比較例

重では, いずれのタイプにおいても 4 と厌の根尖部に 大きな応力集中が認められた。「5の遠心偏心荷重では, $\sqrt{5}$ 根尖部のに大きな纫力集中の他に, タイプ A におい

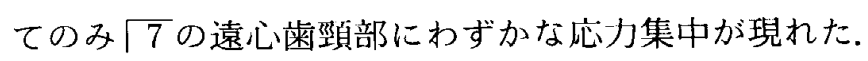

$\lceil 7$ の近心偏心荷重では（表 1, 図 7 ），いずれの夕イプ においても根尖に大きな心力集中がみられ，さらにタイ プ A とCでは「有心歯頸部にわずかな伈力集中が認 められた。 7 の遠心偏心荷重では（表 1 , 図 8 ), 他の 場合と比較して最も多くの部位に応力集中がみられた。 すなわち, 7 の根尖部に大きな応力集中が認められる

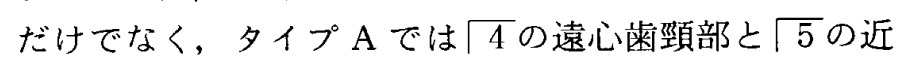
心歯頸部にわずかな伈力集中があり，タイプ B，C 扰よ び D には「7の遠心歯頸部に応力集中がみられた。 とく にタイプDにおいて，他のタイプの場合より 7 遠心側 歯頸部での応力集中が大きく現れた。

III. 傾斜荷重時の応力分布

中央荷重に対しては, 垂直荷重の結果とほとんど同様 の傾向を示していた.

偏心荷重においても垂直荷重時の場合とほぼ同じ傾向 がみられたが, タイプDのて7の近心および中央荷重で は, $\sqrt{6} の$ 遠心顎堤部に垂直荷重の場合に比較して約 2 倍の強さの縞次数が観察された（図 9 ).

\section{考察}

歯の動摇は, 歯周ポケットの増大あるいは雬槽骨の吸 収に伴う歯冠一歯根長比の堌大などが原因で起こる支持 能力の低下によって生じると考えられる ${ }^{22}$. 本実験で は, 㐘周ポケットは正常であるが, 歯冠一歯根長比に問 題がある動摇歯を対象とした。
ブリッジの設計は，著者らの統計的観察 ${ }^{(3)}$ によると下

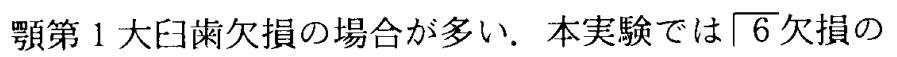
ブリッジとしたが, 通常「57の支台霜が健全であれば, (5) 6(7)のブリッジが合着される。ここでは, $\sqrt{5}$ が動摇 歯の場合であると仮定して設計を行い， 4 を支台㐘之 して追加した、 $\sqrt{4}$ と「7は健全歯または動摇㐘の場合が 考えられるため, 支台歯の条件を 4 タイプに分類して実 験を行った。

垂直中央荷重では，いずれの症例においても，荷重を 受ける根尖部にだけ応力集中が認められた。ただし， $\sqrt{6}$ のポンティック部の中央荷重では $\sqrt{5}, \sqrt{7}$ の根尖部に 応力集中がみられた。これは, 柬が欠損している部位に 荷重を加えたために，偏心荷重と同様の傾向を示したす のと思われる。

垂直偏心荷重では, いずれも荷重に近い歯の根尖部に 大きな攵集中が認められた。根尖部を除いた雨頸部に 出現する応力集中を荷重点ごよにみると, 結果的に $\sqrt{4}$ の近心に $1 つ, \sqrt{5}$ に 1 つおよび「7の近遠心合わせ て8つみられる. タイプ別に応力集中の場所を数えてみ ると, タイプAで6つ, タイプ Bで1つ, タイプCで 3 つおよびタイプ Dで1つとなり, タイプ B, D が比 較的少ない，タイプ B，Dはいずれも「が健全歯の場 合である. タイプ BとDの縞次数を比較すると, 夕イ プ Bの方が望ましいといえる.すなわち， 47 とも健 全歯であれば, ブリッジの予後はかなり期待できるむの と考えられる. 7 が動摇歯の場合のタイプ A と C を比 較する之, 「が健全歯である夕イプ A の方がタイプ C よりあ応力集中の数が多い：これは厉が動摇している ので, 健全な「4でブリッジ全体を支えていることを意 
味している。このような状態が長く続くと，いずれ $\lceil 4$ あ動摇してくるものと思われる. タイプC の場合の ブリッジの両端が動摇歯の場合は，表 1 のタプ B の $\lceil 7$ の遠心荷重に対する結果と同様な傾向を示している. これは 47 の両方とも動摇しているために, 荷重が加 えられたときに，均等に動摇したもの之考えられる. $\lceil 7$ の遠心荷重に対しては「厉の遠心歯頸部にやや大きな 応力集中がみられた。多根柬である める容積が大きく，したがって他の $\longdiv { 4 5 }$ の状態にかか わらず，ブリッジを固定させる役割が大である。 7 が 動摇していると, 7 が健全な場合と比較して応力集中 部の数が多い. 7 が健全であれば，ブリッジの動きを 7 で受けとめょうとして 7 の遠心歯頸部に応力集中が 認められ, 縞次数が大きく出て 77 に加わる負担が他の 45に比べて大であることがわかる．これらの応力分 布の分析から, (4)(5) 6(7)ブリッジの支台歯の変位に対 する抵抗の多くは「7の歯槽骨に依存しているものと推 測される。

中央荷重を加えた場合，垂直荷重と歯軸に対して $10^{\circ}$ の傾斜荷重との間には，応力分布の傾向に大きな違いは みられなかった。 $10^{\circ}$ の傾斜では傾斜荷重による側方分 力の影響がさほよ゙大きく現れなかったためであろうと考 えられる. しかし，タイプDの 7 の近心および中央に それぞれ荷重を加えたところ， $\sqrt{6}$ の遠心顎堤部にわず かなモアレがみられた。これは厉が側方荷重によって 近心傾斜する傾向を示すためであろうと思われる.

本実験におけるブリッジの支台歯として， 457 を用 いたが， 47 はブリッジの両端にある支台㐘であるとい う点に注目する必要がある、【が健全㐘の場合と動摇 歯の場合を比較してみると、「が動摇歯の場合のほう が「7の遠心歯頸部にあらわれる縞次数が大きい。この ことは, ブリッジにかけられた荷重に対して， 4 が健 全歯であれば，その荷重を負担することができる。しか し，動摇歯であれば，その負担能力が弱いために，その 荷重を「7がより大きく負担することになる.

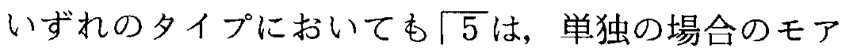
レパターン（図 2）と比較して歯頸部での応力集中が著 しく滅少している.このことから, 動摇歯はブリッジの 支台霜の中に組み込まれることによって固定され，動摇 度が著しく減少することがわかる。また，動摇蒾㧁お

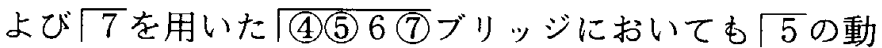
摇は抑えられており, 47 が動摇菊であっても支台茵之 して利用することができることがわかった。しかし，ブ リッジ支台歯の負担を軽減するためには, 47 とくに
「7が健全歯であることが好ましいといえる.

\section{結＼cjkstart論}

$\sqrt{6}$ が欠損, $\sqrt{5}$ が動摇㐘の場合を想定し，4タイプの ブリッジモデル（(4)(5)6(7) ) を設計した。それぞれの ブリッジに垂直の中央荷重および偏心荷重, 傾斜した中 央荷重执よび偏心荷重の 4 種類の集中荷重をかけて縞次 数の測定を行った結果, 次のような結論を得た.

1.「5の動摇歯はブリッジにして固定すれば，動摇 度が著しく減少した。

2. 中央荷重では，すべてのタイプで荷重を受ける根 尖部に大きな沈力集中が認められた。

3．偏心荷重では，荷重点に近い歯牙の根尖部に大き な応力集中がみられ，健全歯の歯頸部に応力集中が多く 認められた。いずれのタイプにおいてもて がみられた。

以上のことから， 5 が動摇歯であっても 7 が健全歯 であれば, (4)(5)6(7)ブリッジの予後は良好であること が示唆された。

\section{文献}

1）小室 甲，松並謙二，本郷智英：動摇菌を支台としたブ リッシ．動摇歯の処置（川崎 仁他編）。菌界展望/別冊. 医画薬出版, 東京, 1986, 223-236.

2) 染谷成一郎：動摇㐘の補経処置と予後. 動摇歯の処置（川 崎 仁他編). 歯界展望/別冊. 医茵薬出版, 東京, 1986, $279-290$.

3）篠原直幸：接着性補緅物が㐘牙の動摇度と支持組織の負担 力に及ぼす影響。補綴誌 33 (1)：158-169，1989.

4) Glickman, I., Roeben, F. W., Brion, M. and Pameijer, J. H. N.: Photoelastic analysis of internal stress in the periodontium created by occlusal forces. J. Periodont. $41: 30-35,1970$.

5) Kratochvil, F. J., Thompson, W. D. and Caputo, A. A.: Photoelastic analysis of stress patterns on teeth and bone with attachment retainers for removable partial dentures. J. Prosthet. Dent. 46:21-28, 1981.

6) Mattison, G. D.: Photoelastic stress analysis of castgold endodontic posts. J. Prosthet. Dent. 48: 407-411, 1982.

7）田中真理子：咬合力下における画牙および歯槽壁の応力分 布に関する光弾性的研究. 九州歯会誌 39 (2)：249$256,1985$.

8) 田中真理子：数個のネジで結合された弾性板の応力分布に ついて. 九州㐘科大学進学課程研究紀要 $18: 21-26$, 1987.

9）四条 進：中問菌欠損型架工義蒾装着による茵槽骨変化の 二次元光弾性実験. 蒾学 $64(3): 640-649,1976$.

10）小野喜市：中間歯 2 歯欠損型架工義歯装着に上る歯槽骨変 
化の二次元光弾性実験. 歯学 68 (4):630-641, 1980.

11）吉江弘正: 支台雨, 維持歯となる㐘の予後判定. カラーア トラス 雬周一補綴治療 (井上昌幸他編). 医雬薬出版, 東京, $1991,78-86$.

12）石川 烈, 長澤敏行：動摇雨の固定の適否をどう診断する か一これまでの研究経過を通して考える一. 補緅臨床 27
(2): 191-197. 1994.

13）村上繁樹，守川雅雄，鱒見進一，有田正博，小城辰郎，佐 藤義輝, 稲永 悟, 大西俊之, 杉本照幸, 豊田静大, 内田 康也：九州䨑科大学附属病院補経科来院患者の統計的観察 （1979～1983 年）第 3 報 歯冠修復物について. 九州蒾 会誌 44 (2): $360-375,1990$. 